\title{
HUBUNGAN SKOR SOFA DENGAN LAMA RAWAT INAP PASIEN CEDERA KEPALA BERAT DI ICU RSUP PROF. DR. R. D. KANDOU PERIODE JUNI 2012- OKTOBER 2013
}

\author{
1. Alfani Filani Idie \\ 2. Diana Lalenoh \\ 3. Iddo Posangi \\ ${ }^{1}$ Kandidat Skripsi Program Studi Kedokteran Umum Fakultas Kedokteran Universitas Sam \\ Ratulangi \\ ${ }^{2}$ Bagian Anestesiologi dan Terapi Intensif Fakultas Kedokteran Universitas Sam Ratulangi \\ Email: idiealfiani@gmail.com
}

\begin{abstract}
ABSTRAK
Lama rawat inap adalah periode waktu pasien berada di rumah sakit atau fasilitas kesehatan lainnya sebagai pasien rawat inap. Pada pasien cedera kepala, lama rawat inap dipengaruhi kegagalan sistem organnya. Pasien cedera kepala yang dirawat di ICU setengah diantaranya mengalami kegagalan organ multiple. Penelitian ini bertujuan untuk menganalisis hubungan antara skor SOFA dengan lama rawat inap pasien cedera kepala berat di ICU RSUP. Prof. DR. R. D. Kandou. Penelitian ini adalah penelitian analitik retrospektif dengan sampel sebanyak 10 pasien. Uji stastistik dilakukan dengan spearman. Berdasarkan hasil uji statistik, $\mathrm{r}=$ 0,190 dan $p=0,599$. Hasil ini menyatakan tidak terdapat hubungan yang bermakna antara skor SOFA dengan lama rawat inap pada pasien cedera kepala di ICU.
\end{abstract}

Kata kunci: Skor SOFA, Lama Rawat Inap, Cedera Kepala Berat

\begin{abstract}
Length of stay is the period of time the patient is in a hospital or other health facility as an inpatient. In patients with head injury, length of stay affected organ system failure. Head injury patients admitted to the ICU half of them suffered multiple organ failure. This study aims to analyze the correlation between SOFA score with a long hospitalization severe head injury patients in the ICU RSUP Prof. DR. R. D. Kandou. This study is a retrospective analytic study with a sample of 10 patients. Statistical test performed with Spearman. Based on the results of statistical tests, $r=0.190$ and $p=0.599$. These results suggest there is no significant correlation between the SOFA score with a long hospitalization in patients with head injury in the ICU.
\end{abstract}

Keywords: SOFA score, Long Of Stay, Severe Head Injury 
Cedera kepala merupakan salah satu penyebab kematian terbanyak didunia. Di Amerika, cedara kepala merupakan faktor yang berkontribusi terhadap sepertiga (30,5\%) dari semua kematian, setiap tahun tercatat 1,7 juta kasus cedera kepala, 52.000 pasien meninggal dan selebihnya dirawat inap. ${ }^{\mathbf{1 , 2}}$ Cedera kepala berat dengan GCS kurang dari 8, memiliki angka kematian sekitar 60\%. ${ }^{3}$ Selain itu, pasien cedera kepala juga memiliki rawat inap di Intensive Care Unit (ICU) yang panjang. Pada suatu penelitian menunjukan, 126 pasien trauma kepala yang dirawat di ICU memiliki ratarata lama rawat inap 9,8 $\pm 8,7$ hari. ${ }^{4}$ Lama rawat inap dipengaruhi kegagalan sistem organnya. Pasien cedera kepala yang dirawat di ICU setengah diantaranya mengalami kegagalan organ multiple. Kegagalan organ multiple ini merupakan penyebab utama morbiditas dan mortalitas pada pasien yang sakit kritis. Pada suatu penelitian yang melibatkan 322 pasien trauma yang dirawat di ICU, 47\% mengalami kegagalan organ multiple, sedangkan $28 \%$ lainnya mengalami kegagalan organ tunggal.,

Untuk mengetahui sejauh mana kegagalan organ tersebut, ada beberapa sistem skoring yang dapat di pakai, salah satunya adalah Skor SOFA atau skor Sequential Organ Failure Assessment. Skor SOFA ini dapat menggambarkan disfungsi atau kegagalan organ pada pasien trauma. ${ }^{7}$ Skor SOFA terdiri dari skor enam sistem organ (pernapasan, jantung, saraf, hati, ginjal, dan koagulasi), dengan jumlah skor berkisar dari 0 sampai 24 poin. ${ }^{8}$ Angka morbiditas dan mortalitas cedera kepala yang tinggi, serta lamanya rawat inap yang disebabkan kegagalan organ, sehingga penulis tertarik untuk meneliti hubungan Skor SOFA dengan lama rawat inap pasien trauma kepala di ICU RSUP Prof.DR .R. D. Kandou Manado.

\section{METODE PENELITIAN}

Penelitian ini adalah penelitian analitik retrospektif dengan pengumpulan data skor SOFA pasien cedera kepala berat yang dirawat di ICU RSUP Prof.Dr.R.D.Kandou Manado periode Juni 2012 - Oktober 2013. Data dievaluasi dan dianalisis untuk melihat hubungannya dengan lama rawat inap. Lokasi penelitian ini mengambil tempat di RSUP Prof. DR. R.D. Kandou Manado dengan Sampel yang di gunakan adalah pasien Cedera kepala berat yang dirawat di ICU RSUP Prof. DR. R. D. Kandou. Sampel yang digunakan sebanyak 10 pasien, lakilaki maupun perempuan, umur 17-55 tahun dan tanpa mengambil data pasien yang telah meninggal dunia.

\section{HASIL PENELITIAN}

Dari 10 jumlah sampel, sebagian besar skor SOFA kurang dari 6 yaitu 9 pasien atau sebesar 90\%, sedangkan yang lebih dari 6 berjumlah 1 kasus atau sebesar 10\%.

\begin{tabular}{ccc}
\hline \hline Skor SOFA & Jumlah & $\%$ \\
\hline$<6$ & 9 & 90 \\
$6-15$ & 1 & 10 \\
$>15$ & 0 & 0 \\
\hline Total & 10 & 100 \\
\hline \hline
\end{tabular}

10 jumlah sampel yang diteliti 40\% memiliki lama rawat inap 4 sampai 6 hari yakni 4 pasien, 30\% memiliki lama rawat inap 1 sampai 3 hari yakni 3 pasien, 20\% memiliki lama rawat inap 7-9 hari yakni 2 orang dan yang $>10$ hari hanya $10 \%$ yakni 1 orang.

\begin{tabular}{ccc}
\hline \hline $\begin{array}{c}\text { Lama Rawat } \\
\text { Inap }\end{array}$ & Jumlah & $\%$ \\
\hline $1-3$ & 3 & 30 \\
$4-6$ & 4 & 40 \\
$7-9$ & 2 & 20 \\
$>10$ & 1 & 10 \\
\hline Total & 10 & 100 \\
\hline \hline
\end{tabular}

Pasien cedera kepala berat yang paling banyak berada pada kelompok usia kurang 
dari 30 tahun yang berjumlah 5 pasien (50\%) dari keseluruhan subjek penelitian, selanjutnya kelompok umur 30 sampai 40 tahun berjumlah 3 pasien (30\%), sisanya 2 pasien (20\%) berada pada kelompok umur 41-50.

\begin{tabular}{ccc}
\hline \hline Umur & Jumlah & $\%$ \\
\hline$<30$ & 5 & 50 \\
$30-40$ & 3 & 30 \\
$41-50$ & 2 & 20 \\
$51-60$ & 0 & 0 \\
\hline Total & 10 & 100 \\
\hline \hline
\end{tabular}

Setelah dilakukan uji korelasi dengan spearman, didapatkan hasil yaitu, $r=0,190$ dan $p=0,599$. Hasil ini menyatakan tidak terdapat hubungan yang bermakna antara skor SOFA dengan lama rawat inap pada pasien cedera kepala di ICU.

\begin{tabular}{lcc}
\hline \hline & $\begin{array}{c}\text { Skor SOFA } \\
\text { (p) }\end{array}$ & $\begin{array}{c}\text { Lama rawat } \\
\text { inap } \\
(\mathrm{r})\end{array}$ \\
\hline \hline Skor SOFA & - & 0,190 \\
Lama Rawat & 0,599 & - \\
Inap & 10 & \\
$\mathrm{~N}$ & 10 \\
\hline \hline
\end{tabular}

\section{PEMBAHASAN}

Terdapat beberapa faktor yang dapat mempengaruhi lama rawat inap pasien cedera kepala berat yang di rawat di ICU, diantaranya usia pasien saat dirawat serta sejauh mana kegagalan organ yang di alami pasien tersebut. $^{9}$

Rata-rata hasil penelitian tersebut sedikit berbeda dengan penelitian Sut N (2010) pada 126 pasien trauma kepala yang dirawat di ICU,dimana rata-rata lama rawat inap 9,8 $\pm 8,7$ hari. $^{4}$

Pasien cedera kepala berat yang dirawat di ICU setengah diantaranya mengalami kegagalan organ multiple dan yang lainnya mengalami kegagalan organ tunggal. Penelitian Ciesla (2005) pada 322 pasien cedera yang dirawat di ICU, 47\% mengalami kegagalan organ multipel, sedangkan $28 \%$ lainnya mengalami kegagalan organ tunggal. ${ }^{6}$

Skor SOFA adalah salah satu sistem skroing yang baik digunakan untuk menggambarkan kegagalan organ pada pasien trauma.Skor SOFA terdiri dari skor enam sistem organ (pernapasan, jantung, saraf, hati, ginjal, dan koagulasi), dengan jumlah skor berkisar dari 0 sampai 24 poin. ${ }^{7}$

Pada penelitian ini, nilai skor SOFA di dapat melalui penjumlahan skor tiap-tiap sistem organ, yang diperoleh dari hasil pemeriksaan yang dilakukan pada saat awal pasien masuk ke ICU, dengan melihat pada catatan rekam mediknya. Rekam medik yang dipakai sebagai sampel adalah yang memenuhi kriteria inklusi dan ekslusi.

Berdasarkan penelitian tersebut diperoleh hasil, pasien dengan skor SOFA kurang dari 6 sebanyak 9 orang (90\%) dan pasien dengan skor SOFA 6 sampai 15 sebanyak 1 orang (10\%).

Suatu kegagalan organ yang dinilai dengan skor dapat membantu untuk memperkirakan berapa lama pasien cedera kepala dirawat di ICU. Penelitian Vincent,dkk (1998), pada 181 pasien cedera menunjukan pasien dengan rata-rata SOFA skor $8 \pm 4$ memiliki lama rawat inap 10 hari, dengan $\mathrm{p}<0,05^{8}$

Hasil uji statistik hubungan skor SOFA dengan lama rawat inap pasien cedera kepala di ICU didapatkan nilai $\mathrm{p}=0,599$ ( $\mathrm{p}$ $>0,05)$. Hal ini berarti tidak terdapat hubungan yang bermakna antara skor SOFA dengan lama rawat inap. Hasil ini berbeda dengan penelitian sebelumnya oleh Vincent, dkk (1998). 
Perbedaan hasil dengan penelitian sebelumnya dapat disebabkan jumlah sampel kurang dari yang telah dihitung sebelumnya. Apabila jumlah sampel memadahi, kemungkinan akan diperoleh hasil yg memiliki hubungan bermakna seperti penelitian sebelumnya.

Kekurangan sampel tersebut disebabkan oleh hasil-hasil pemeriksaan penunjang yang dibutuhkan untuk menghitung skor SOFA tidak tercatat dalam rekam medik. Pemeriksaan tersebut diantaranya adalah pemeriksaan Analisa Gas Darah untuk mengetahui nilai $\mathrm{PaO}_{2} / \mathrm{FiO}_{2}$, serta pemeriksaan Bilirubin yang tidak dilakukan pada semua pasien.

\section{KESIMPULAN}

Berdasarkan hasil dan pembahasan yang diperoleh, dapat ditarik kesimpulan bahwa tidak terdapat hubungan yang bermakna antara skor SOFA dengan lama rawat inap pasien cedera kepala berat. Hal ini dapat disebabkan jumlah sampel yang terbatas pada penelitian ini.

\section{SARAN}

1. Pengisian rekam medik sebaiknya diisi dengan lengkap dan jelas

2. Sebaiknya penyimpanan data rekam medik dilakukan secara komputerisasi agar mempermudah dalam pencarian data dikemudian hari

3. Perlu dilakukan penelitian tentang faktorfaktor yang dapat mempengaruhi penilaian skor SOFA dan lama rawat inap.

\section{DAFTAR PUSTAKA}

1. Center for Disease Control and Prevention.Injury Prevention and Control: Traumatic Brain Injury.18 Maret 2013 (diakses 30 September 2013).Tersedia

dari:
http://www.cdc.gov/TraumaticBrainInjur y/index.html

2. Universitas Sumatera Utara.Gambaran Penderita Trauma Kepala yang diRawat di UGD RSUP H.Adam Malik Medan.diakses 30 september 2013. Tersedia dari: http://repository.usu.ac.id/bitstream/123 456789/25734/4/Chapter\%20I.pdf

3. Heegaard W,Biros M.Traumatic Brain Injury.Emerg Med Clin N Am.2007;25:655-78

4. Sut N,Memis. Intensive Care Cost and Survival Analyses of Traumatic Brain Injury.PubMed. 2010; 16: 149- 54.

5. Ciesla DJ, Moore EE, Johnson JL, Burch JM, Cothren CC, Sauaia A. A 12-year prospective study of postinjury multiple organfailure. Arch Surg.2005;140:432438

6. Ulvik A,Kvale R,Larsen TW,Flaatten H.Multiple Organ Failure After Trauma Affects Even Long-Term Survival and Functional Status.BiomedCentral.2007;11:2

7. Ceriani R,Mazzoni M,Bortonw F,Gandini S,Solinas C,Susini G et al. Application of the

Sequential Organ failure Assessment Score to Cardiac Surgical Patients.Chest Journal.2003;123:1229-39

8. Vincent JL, Moreno R, Takala J, Willatts S, De Mendonça A, Bruining H, et al. The SOFA (sepsis-related organ failure assessment) score to describe organ dysfunction/failure. On behalf of the Working Group on Sepsis-Related Problems of the European Society of Intensive Care Medicine. Intensive Care Med 1996; 22: 707-10

9. Frankel JE, Marwitz JH,Cifu DX, Kreutzer JS, Englander J, Rosenthal M. A follow-up study of older adults with traumatic brain injury.Archives of Physical Medicine and Rehabilitation.2004.; 87: 57-62 
